\title{
Power System Modeling and Network Simulation: The Content Validity of the E-MAP Model in Electric Power Transmission Technology
}

\author{
Agus Junaidi ${ }^{1}$, Joni S Rambe ${ }^{2}$, Rudi Salman ${ }^{3}$, Rahmaniar ${ }^{4}$, Rosnelli ${ }^{5}$ \\ \{agusjunaidi@unimed.ac.id ${ }^{1}$,jonirambe@unimed.ac.id ${ }^{2}$, rudisalman@unimed.ac.id ${ }^{3}$, \\ rahmaniar@dosen.pancabudi.ac.id ${ }^{4}$,rosnelli@unimed.ac.id $\left.{ }^{5}\right\}$ \\ Universitas Negeri Medan, Jurusan Pendidikan Teknik Elektro, Medan 1,2,3,4,5
}

\begin{abstract}
E-MAP model is a learning model based on product modeling and simulation. This model was built to meet the learning needs of Electric Power Transmission technology. (EPT) EPT is a higher education course that requires critical thinking skills / HOTS (Higher Other Thinking Skill), because each EPT study material requires mathematical equations. Updating the model that requires EPT-based HOTS learning is done by preparing the EMAP model with the syntax steps of FACTA (Find, Analysis, Construction Modeling of System, Tracking and Assessment). The model development strategy are carried out within 3 main stages, the first stage is to build modeling and simulation products for EPT learning needs, the second stage is to product content validation and the third stage is to syntax construct validation. Validation is carried out by experts in their fields and becomes the main indicator in the successful development of the E-MAP model. The results of this EMAP model development study are: Modeling and simulation products obtained are used in EPT learning and model books that can be used as a reference in HOTS-based EPT learning.
\end{abstract}

Keywords: E-MAP, EPT, HOTS. Modeling and Simulation.

\section{Introduction}

Higher education institutions in Indonesia have a strategic and centralistic role in developing Human Resources (HR) based on competencies and skills. Preparation of reliable HR competencies through strategic policies in the Indonesian National Qualification Framework (KKNI). KKNI comprehensively strengthens the needs of human resources through learning outcomes $(\mathrm{CP})$ in accordance with the interests of stakeholders. HR competencies with suitable, sufficient and fit abilities are carried out through the process of organizing higher education through the learning process. Higher Education Institutions in Indonesia have a strategic role in producing competent and competitive human resources, as well as agents of change towards a better life for the nation. HR competencies generated by tertiary institutions become an important concern in the education community. The State of Indonesia is currently faced with the free market regulation of the ASEAN Economic Community (AEC) which demands that the human resources produced by tertiary institutions have innovative and productive competencies. The quality of productive human resources has relevance to the welfare of a nation. The essence of national welfare can be seen from the aspects of good economic growth and the ability of a nation to compete with other nations [1]. Efforts to develop learning strategies and strengthen $4 \mathrm{C}$ competencies (Communication, Collaborative, Critical Thinking, and Creativity) at the Higher Education level are carried out to produce productive 
and quality Human Resources (HR) for employment. However, at present, the 4C competencies needed through the process of providing education in tertiary institutions are intended to meet the job market in the industrial era 4.0, which is still not optimal. This is due to not maximizing the potential of human resources, technology, innovation, and information so that the workforce in Indonesia is still dominated by HR with the classification of Primary and Secondary Education [2]. Strengthening the capacity and learning ability of students can be developed through the construction of student-centered learning. Learning activities that focus on student centering are the most important contributions of constructivism. Constructivism is part of a learning theory found in educational psychology that explains how people can gain knowledge and learning, because it has direct application to education with knowledge ideas developed and that constructivist educators invite students to continue to assess how this activity helps students gain understanding [3].

The concept of learning through knowledge construction is actively carried out by students, supported by students' Higher Order Thinking Skills (HOTS). The domain of critical thinking skills can be done with learning strategies based on modeling, analysis and simulation. Learning with the HOTS strategy entitled [4,5]. Analysis of question papers in engineering courses with Respect To HOTS explains the importance of learning strategies with HOTS thinking skills managed by the Faculty of Engineering. Bloom's Taxonomy Approach at the HOTS level as an active learning strategy to improve students' critical thinking skills and creative thinking skills. Educational institutions in the engineering department are required to facilitate managerial management of HOTS-based learning, to further encourage critical thinking and creative thinking from students so that students do not only remember facts or general information. This is closely related to the problems of the needs of the world of work that requires graduates in the field of engineering in order to have the ability to formulate, develop, and understand practical problems as a challenging task.

Efforts to create an active learning platform for students with HOTS strategy are carried out through an investigation-based learning approach and simulation products. Through inquirybased learning characteristics assisted with computer technology, an E-MAP learning model was developed in the field of engineering electric power transmission technology, which requires a HOTS strategy in the learning process.

\section{Theory of developing the E-MAP Model}

The E-MAP model is built on the basis of an educational philosophy, as shown in figure 1. The PSE approach through P, PS and PE integration results in a PSE rule in the development of science and technology. 


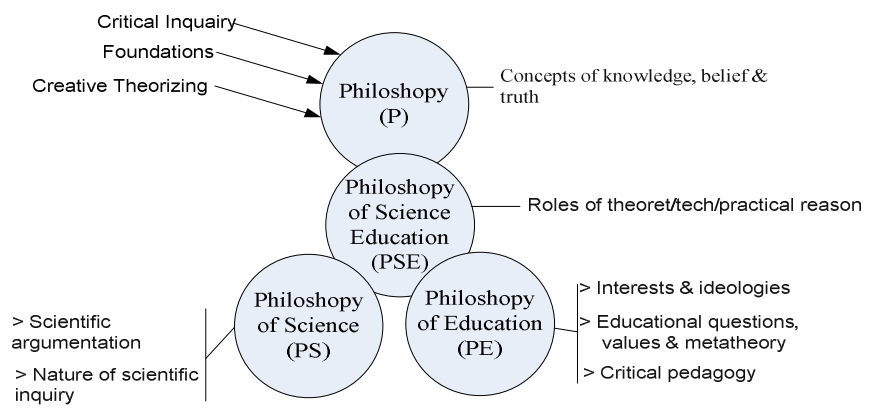

Fig.1. Philosophy of science education PSE [6]

The concept of developing the E-MAP model in this study pays attention to 3 important aspects in the study of the philosophy of science namely ontology, epistomology and axiology. The term 3 aspects of this philosophy have understanding, namely: 1) Ontology; from the Greek language which has meaning about existing knowledge, in the sense that the study of something or things that already exist, both spiritually and physically. In the ontology aspect, an important foundation of statements in a science is needed, 2) Epistomology; is an aspect of the philosophy of science that states that how to seek knowledge and understand the meaning of knowledge, so that with this knowledge individuals know the limitations in studying science 3) Axiology; is an aspect of the philosophy of science that deals with quality or value, discusses how science can be utilized and used in terms of overcoming the problems of social life [7]

\section{E-MAP Model in learning Electric Power Transmission (EPT)}

Electric Power Transmission (EPT) is a course taught to students in the Electrical Engineering Study Program in Higher Education. The v course discusses the study of electrical power delivery systems with material on the study of voltage profiles, sending and receiving sides, transmission modeling, efficiency, channel regulation on transmission based on the transmission line length classification [8]. The concept of analysis with abstract complexity in EPT learning materials requires critical analytical skills through critical thinking skills. Information is obtained through a questionnaire distributed to lecturers and students, explicitly the results of the questionnaire distribution can be concluded (1). The material concepts delivered at EPT courses with the level of analysis using advanced mathematical equations, require the expertise of HOTS critical thinking skills (2). In the process of solving EPT problems requires a model that can help accelerate students gain a good understanding of EPT material (3). The need for learning aids (computer technology) becomes an important tool for students in solving problems of the analysis model in the study of electrical power delivery systems.

From the elaboration of research background related to the importance of electricity competence through the learning process in the EPT field, efforts are needed in realizing the validity, effectiveness and practicality of EPT learning through the mechanism of developing learning models. The characteristics of choosing the right model become the main key in achieving the expected results. The characteristics of the IbL model have characteristics in solving learning problems that require HOTS high-level thinking skills. The field of engineering and analysis of electric power transmission systems, with the selection of the right model in accordance with the characteristics of EPT courses. IbL becomes an important part in learning 
science and technology because the IbL model has stages that meet the criteria for learning needs in the field of science and technology studies including EPT courses. The IbL model is the basis for developing the FACTA model in EPT learning. FACTA Model is a development model with syntax, FACTA (Find, Analysis, Construct Modeling of Systems, Tracking, Assessment). The FACTA model was arranged as an effort to improve the quality of learning in EPT subjects, with the development of the FACTA model it is expected to improve the quality of learning in science and technology for electricity engineering courses in EPT subjects in the Electrical Engineering Study Program at the College.

\section{Methodology}

The concept used in developing the E-MAP model is shown in the mechanism of model development as shown in figure 2 .

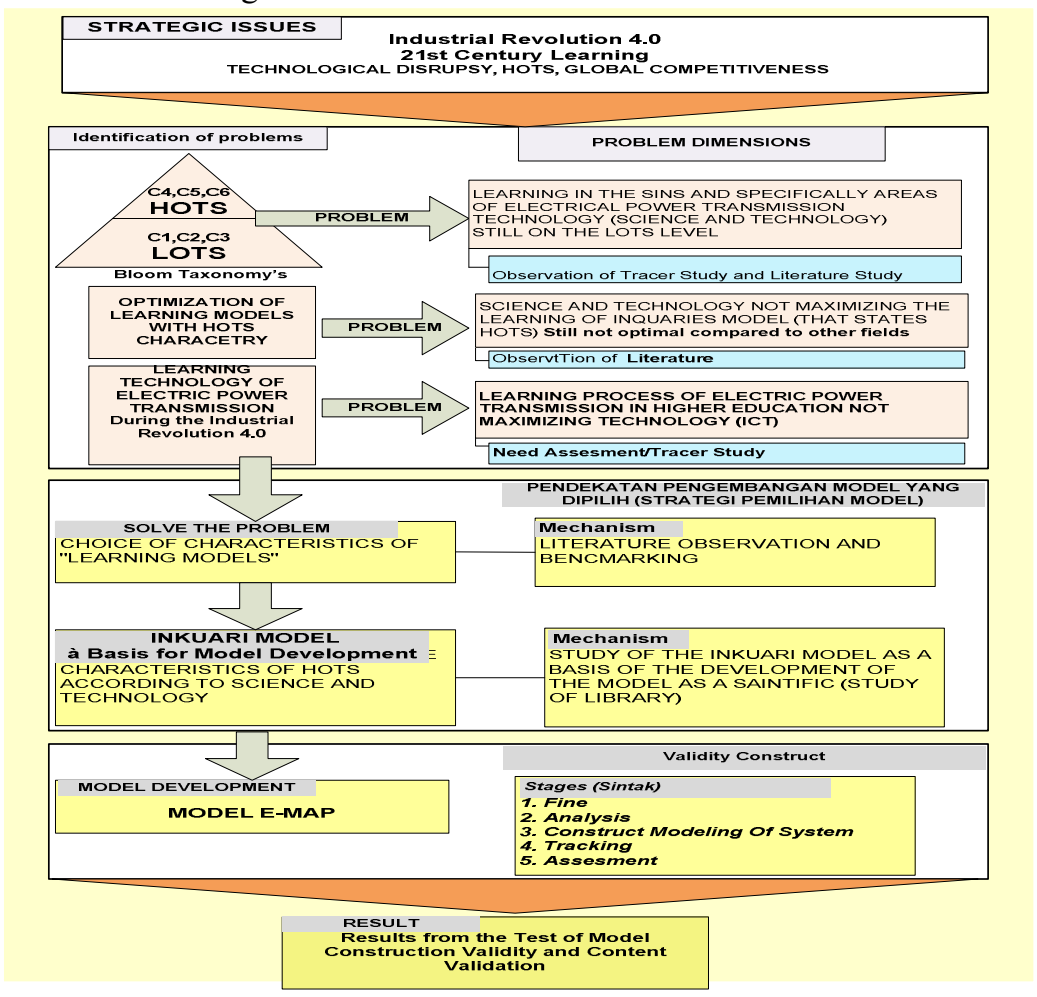

Fig 2. The concept of developing the E-MAP Model

Figure 2 shows a conceptual framework diagram for the development of the PACTA Model. Starting from the strategic issue of 21 st century learning, the integration of technology in learning with the need for critical thinking skills to meet the needs of work in the era of technological disruption. The rationale related to the problem raised is that learning is not optimal in the Electric Power Transmission (TDL) course, because TDL learning is still at the LOTS level so the TDL learning outcomes are not optimal. Technology integration, ICT utilization and HOTS thinking skills strategy in TDL learning are not optimal. 
Learning models that meet the characteristics of HOTS are observed through literature study, questionnaire distribution and benchmarking activities. The model that meets the characteristics of HOTS is a model that meets the criteria of the level $\mathrm{C} 4$ to $\mathrm{C} 6$ cognitive domain at the level of critical thinking of Bloom's Taxonomy. IbL with the characteristics of learning centered on students, develops the concept of independent learning, knowledge is constructed by students through investigation (investigation) so that critical thinking skills are developed by students to solve problems. IbL became a model that was adapted for the development of the FACTA model to solve TDL learning problems. The FACTA model is a development model for answering EPT learning problems that require HOTS skills. The FACTA model is applied to determine the validity, practicality and effectiveness of the model in EPT learning.

\section{Results and Discussion}

\section{a. Simulation Product}

The results achieved in this study are the development of simulation products for Electric Power System Networks using software. One part of the simulation results as shown in figure 3

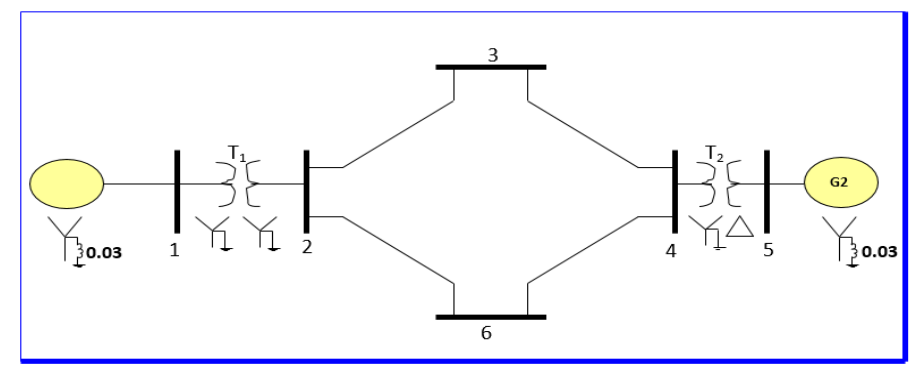

Fig 3. Single Line Diagram EPT

Table 1. Data (Single Line Diagram EPT)

\begin{tabular}{lccccc}
\hline ITEM & MVA RATING & VOLTAGE RATING & $\mathrm{X}_{1}(\mathrm{PU})$ & $\mathrm{X}_{2}(\mathrm{PU})$ & $\mathrm{X}_{0}(\mathrm{PU})$ \\
\hline $\mathrm{G} 1$ & 100 & $13,8 \mathrm{kV}$ & 0.2 & 0.2 & 0.05 \\
$\mathrm{G} 2$ & 100 & $13.8 \mathrm{kV}$ & 0.2 & 0.2 & 0.05 \\
$\mathrm{~T} 1$ & 100 & $13.8 / 230 \mathrm{kV}$ & 0.05 & 0.05 & 0.05 \\
$\mathrm{~T} 2$ & 100 & $13.8 / 230 \mathrm{kV}$ & 0.05 & 0.05 & 0.05 \\
$\mathrm{~L}_{23}$ & 100 & $230 \mathrm{kV}$ & 0.1 & 0.1 & 0.3 \\
$\mathrm{~L}_{26}$ & 100 & $230 \mathrm{kV}$ & 0.1 & 0.1 & 0.3 \\
$\mathrm{~L}_{34}$ & 100 & $230 \mathrm{kV}$ & 0.1 & 0.1 & 0.3 \\
L46 & 100 & $230 \mathrm{KV}$ & 0.1 & 0.1 & 0.3 \\
\hline
\end{tabular}

\section{Simulation Results}

Total fault current $=5.7143$ per unit Bus Voltages during fault in per unit

\begin{tabular}{|c|c|c|}
\hline $\begin{array}{l}\text { Bus } \\
\text { No. }\end{array}$ & $\begin{array}{l}\text { Voltage } \\
\text { Magnitude }\end{array}$ & $\begin{array}{l}\text { Angle } \\
\text { degrees }\end{array}$ \\
\hline 1 & 0.4286 & 0.0000 \\
\hline 2 & 0.2857 & 0.0000 \\
\hline 3 & 0.0000 & 0.0000 \\
\hline 4 & 0.2857 & 0.0000 \\
\hline 5 & 0.4286 & 0.0000 \\
\hline 6 & 0.2857 & 0.0000 \\
\hline
\end{tabular}

Line currents for fault at bus No. 3

\begin{tabular}{|c|c|c|c|}
\hline $\begin{array}{l}\text { From } \\
\text { Bus }\end{array}$ & $\begin{array}{r}\text { To } \\
\text { Bus }\end{array}$ & $\begin{array}{l}\text { Current } \\
\text { Magnitude }\end{array}$ & $\begin{array}{l}\text { Angle } \\
\text { le degrees }\end{array}$ \\
\hline $\mathrm{G}$ & 1 & 2.8571 & -90.0000 \\
\hline 1 & 2 & 2.8571 & -90.0000 \\
\hline 2 & 3 & 2.8571 & -90.0000 \\
\hline 2 & 6 & 0.0000 & -90.0000 \\
\hline 3 & $\mathrm{~F}$ & 5.7143 & -90.0000 \\
\hline 4 & 3 & 2.8571 & -90.0000 \\
\hline 4 & 6 & 0.0000 & -90.0000 \\
\hline $\mathrm{G}$ & 5 & 2.8571 & -90.0000 \\
\hline 5 & 4 & $2.8571-90$ & 0.0000 \\
\hline
\end{tabular}


The simulation shows the tracking data of the SCC analysis to determine the Breaker capacity of the EPT system through symmetric interference analysis. This is a part of the product that resulted from the development of the E-MAP model

\section{b. Results of Validation of Syntax Constructions}

The syntactic construct of the E-MAP model was tested using Lisrel software. From the results of the validity test using the Lisrel program, the validity test results are shown in Table 2.

Table 2. Resume of the results of the syntax construct validation test

\begin{tabular}{cclllll}
\hline Syntax & $\mathbf{X}^{\mathbf{2}}$ & $\mathbf{d f}$ & $\mathbf{p}-\mathbf{v a l u e}$ & $\mathbf{R S M E A}$ & $\mathbf{X}^{\mathbf{2}} / \mathbf{d f}$ & Result \\
\hline $\mathrm{F}$ & 7,33 & 14 & 0,92 & 0,00 & 0,52 & Goodness-of-fit \\
$\mathrm{A}$ & 1,14 & 2 & 0,56 & 0,00 & 0,57 & Goodness-of-fit \\
$\mathrm{C}$ & 2,70 & 5 & 0,59 & 0,00 & 0,74 & Goodness-of-fit \\
$\mathrm{T}$ & 0,52 & 2 & 0,77 & 0,00 & 0,26 & Goodness-of-fit \\
$\mathrm{A}$ & 0,57 & 2 & 0,75 & 0,00 & 0,28 & Goodness-of-fit \\
\hline
\end{tabular}

\section{c. Content Validation Test Results}

Content validity based on Aiken s V validation test [9] in his research he tested 55 respondents and the coefficient of validity based on the Aiken's V approach was 0.83 and was stated to be significant in meeting the content validity criteria of research on the Validity Study and Reliability for E-Government Success Factors. Aikens V is used to test the validity of the contents of the E-MAP Model against 2 book products produced and assessed by experts / experts declared valid

\section{Conclusion}

Conclusions from the Development of the E-MAP model are:

1. The E-MAP model produces EPT learning products with HOTS characteristics because it is supported by simulation products on the EPT system

2. The validation results of the syntax construct and the E-MAP model with the FACTA syntax is valid.

3. The content validation of the EPT learning module and the Lecturer Guide is valid

\section{References}

[1] Ganna Kharlamova, Olga Vertelieva,.The International Competitiveness of Countries: EconomicMathematical Approach, The International Competitiveness of Countries: Economic-Mathematical Approach, Economics \& Sociology, Vol. 6, No 2, pp. 39-52, (2013). DOI: 10.14254/2071789X.2013/6-2/4. 
[2] Gufron, Report Rekomendasi Rakernas Kemenristekdikti. Kemenristek DIKTI, Semarang 3-4 Januari 2019.

[3] Bada. Constructivism Learning Theory: A Paradigm for Teaching and Learning" IOSR Journal of Research \& Method in Education (IOSR-JRME) e-ISSN: 2320-7388,p-ISSN: 2320-737X Volume 5, Issue 6 Ver. I (Nov. - Dec. 2015), PP 66-70

[4] Narayanan S. Analysis of Question Papers In Engineering Courses With Respect To Hots (Higher Order Thinking Skills)“, American Journal of Engineering Education (June 2015).

[5]. Rahmaniar. Model FLASH-NR pada Analisis Sistem Tenaga Listrik, ISBN 978-623-90918-7-3, (2019).

[6]. Schulz. Philosophy of Education and Science Education: A Vital but Underdeveloped Relationship, Imaginative Education Research Group (IERG), Faculty of Education, Simon Fraser University, Vancouver, BC, Canada, (2014).

[7] Bahrum.”Ontologi, Epistemologi Dan Aksiologi. Sulesana, Volume 8 Nomor 2 (2013)..

[8]. Georgios Leonidopoulos, 2015, Modelling and Simulation of Electric Power Transmission Line Voltage, ASME Journals, (2015).

[9] Darmawan. Validity and Reliability Study for E-Government Success Factors. ReasearchGate, (February). doi: 10.1109/CITSM.2014.7042165, (2015). 